\title{
PHOTOSYNTHETIC APPARATUS EFFICIENCY OF SIDA HERMAPHRODITA CULTIVATED ON HEAVY METALS CONTAMINATED ARABLE LAND UNDER VARIOUS FERTILIZATION REGIMES
}

\author{
Szymon RUSINOWSKI ${ }^{1}$, Jacek KRZYŻAK, Marta POGRZEBA \\ Institute for Ecology of Industrial Areas, Katowice, Poland
}

\begin{abstract}
Contaminated and marginal lands are favourable place for biomass feedstock establishment, especially due to European Union directive 2009/28/EC. This strategy not only cover local demand for energy and heat but also can be valuable in those land phytomanagment. The second-generation perennial energy crop species are the most feasible for such purpose. We studied the impact of two different fertilizer treatments on plant physiological parameters associated with photosynthesis, heavy metals (HMs) and primary macronutrients accumulation in Sida hermaphrodita cultivated on HMs contaminated soil under field conditions. NPK fertilized plants showed the highest values of photosynthetic parameters at the beginning of growing season when compared to control and microbial inoculated plants. However, at the end of the growing season inoculated and control plants showed better photosynthetic performance than NPK treated. NPK fertilizer caused higher $\mathrm{Cd}$ and $\mathrm{Zn}$ shoot concentrations while microbial inoculation caused higher $\mathrm{K}$ and the lowest $\mathrm{N}$ and $\mathrm{P}$ concentrations in shoot. Due to $\mathrm{Cd}$, $\mathrm{Pb}$ and $\mathrm{Zn}$ concentrations in plants which should not result in alleviation of photosynthetic apparatus efficiency and biomass production it could be summarize that Sida hermaphrodita is a suitable plant for cultivation on land contaminated with HMs under different fertilization regimes.
\end{abstract}

Keywords: photosynthesis rate, chlorophyll fluorescence, $\mathrm{Cd}, \mathrm{Pb}, \mathrm{Zn}$, senescence

\footnotetext{
1 Corresponding author: Institute for Ecology of Industrial Areas, Kossutha st 6, 40-844 Katowice, Poland, e-mail: s.rusinowski@ietu.pl, tel. +48322546031 ext. 231
} 


\section{INTRODUCTION}

Biomass is an organic material which derived from plants (including algae, trees and crops), strictly from conversion $\mathrm{CO}_{2}$, water, mineral nutrients and the sunlight in to carbohydrates, which are plant structure building matter, and oxygen via photosynthesis [1]. The process and strength of photosynthesis directly affect the yield and quality of plants [2]. Besides the classic measurements of photosynthesis activity of plants by gas-exchange analysis, chlorophyll fluorescence allow evaluating photosynthesis apparatus status of plants based on detection changes in some photosystem II (PSII) components, electron transport chain components, and light dependent photochemical reactions [3,4]. Additionally, chlorophyll content has great importance in estimation photosynthetic apparatus efficiency and general plant health [5].

Due to conventional energy sources decrement any environmental-saving technology, especially in industry, are desirable. Limitation of conventional heat production technology, based mainly on fossil fuels for increase usage of biobased energy sources, especially biomass is the first step to improve environment condition.

Renewable energy directive (RED) 2009/28/EC [6] promote usage of renewable energy sources in the members of European Union. These countries have to increase the share of renewable energy of gross final energy consumption to 20 $\%$ in 2020. That directive also excludes several land categories from biomass production, especially lands with high biodiversity value and high carbon stock, what made marginal and degraded lands a favourable place to energy crops cultivation [7].

Marginal lands could be contaminated by many different compounds or/and harmful elements, which have got anthropogenic or environmental origin. That contamination can significantly affect the quality of agricultural products [8]. Heavy metals could alter the photosynthetic activity indirectly, decreasing the content of photosynthetic pigments or damaging the photosynthetic apparatus on every level of its organization [9]. For this reason, analysis of energy crops photosynthetic apparatus efficiency, while growing on contaminated soil is very important.

Cultivation of energy crops on such contaminated soil especially on heavy metal contaminated (HMC) soil can be profitable not only in biomass production but also in phytoremediation [10].

Nowadays biomass production is focused on second generation bioenergy crops. Such plants have got less inputs requirement, produce more energy and reduce greenhouse gases emission more than annual crop species belonging to first generation [11]. Sida hermaphrodita as a $\mathrm{C}_{3}$ photosynthesis perennial plant species was already cultivated for energy purposes $[12,13]$. 
The aim of the study was to assess influence of two different fertiliser treatments on plant physiological parameters associated with photosynthesis, heavy metals (HMs) and primary macronutrients accumulation in S. hermaphrodita cultivated on HMs contaminated soil under field conditions.

\section{MATERIALS AND METHODS}

\subsection{Site description}

The experimental plots were established on contaminated arable land in Bytom (Upper Silesia), Poland (50 $\left.20^{\prime} 43.1^{\prime \prime N} 18^{\circ} 57^{\prime} 17.9^{\prime \prime} \mathrm{E}\right)$ at the beginning of the 2014 growing season, on the area lease by the Institute for Ecology of Industrial Areas. Soil contamination with zinc, cadmium and lead on described area resulted from $\mathrm{Pb} / \mathrm{Zn}$ smelting activity over the last century. Total soil heavy metals (HMs) concentration exceed the threshold values proscribed by Polish government regulation [14], excluding this area from food production. Yearly average values of temperature and sum of precipitation measured during the third growing season (May 2016 - September 2016) were $17.5^{\circ} \mathrm{C}$ and $450 \mathrm{~mm}$ respectively (Institute of Meteorology and Water Management, Poland).

\subsection{Experiment design}

Roots seedlings of Sida hermaphrodita were planted at $10 \mathrm{~cm}$ depths from direct root cuttings which were originated from an uncontaminated site and precultivated in controlled conditions. In the middle of the May 2014 on each from three plots 49 plants were planted over an area of $16 \mathrm{~m}^{2}$ (3 plants per $\left.1 \mathrm{~m}^{2}\right)$ with a buffer zone of $4 \mathrm{~m}$ between each plot which protected plants against uncontrolled fertilisation. Single plot trials with pseudo-replication were performed due to high soil homogeneity on the field before experiment establishment. During plantation establishment, each plot was treated in different way:

- SH I - control, untreated plot

- SH II - plot treated with standard NPK chemical fertilizers (ammonium sulphate and Polifoska - 4\% N, 22\% $\mathrm{P}_{2} \mathrm{O}_{5}, 32 \% \mathrm{~K}_{2} \mathrm{O}$ ) once before planting. Dose was adjusted according to El Bassam [15] and amounts of applied macronutrients were as follow: nitrogen $100 \mathrm{~kg} \mathrm{ha}^{-1}$, phosphorus $80 \mathrm{~kg} \mathrm{ha}^{-1}$ as $\mathrm{P}_{2} \mathrm{O}_{5}$ and potassium $120 \mathrm{~kg} \mathrm{ha}^{-1}$ as $\mathrm{K}_{2} \mathrm{O}$.

- SH III - plot treated with microbial inoculum (Emfarma Plus ${ }^{\circledR}$ ProBiotics, Poland) which consist of Lactic Acid Bacteria $>3.0 \times 10^{5} \mathrm{CFU} \mathrm{ml}^{-1}$, Yeast $<$ $1.0 \times 10^{6} \mathrm{CFU} \mathrm{ml}^{-1}$ and Purple Non-Sulfur Bacteria $>1.0 \times 10^{4} \mathrm{CFU} \mathrm{ml}^{-1}$ in molasses suspension. Inoculum (10\% water solution) was applied on roots and on soil surface ( 81 per plot) before planting. In addition, plant leaves were treated monthly during the growing season by aerosol treatment (81 per plot). 


\subsection{Soil physico-chemical parameters}

Results from initial soil physico-chemical analyses including: $\mathrm{pH}, \mathrm{EC}$, organic matter content $(\mathrm{OM})$, concentration of elements $\mathrm{N}, \mathrm{P}, \mathrm{K}, \mathrm{Mg}, \mathrm{Ca}, \mathrm{Fe}, \mathrm{Pb}, \mathrm{Cd}, \mathrm{Zn}$ as well as bioavailable forms of analysed heavy metals $(\mathrm{Pb}, \mathrm{Cd}, \mathrm{Zn})$ were previously reported for investigated plots by Pogrzeba et al. [12] (Table 1).

Table 1. Soil physico-chemical characteristic according to Pogrzeba et al. [12]

\begin{tabular}{|c|r|r|r|}
\hline \multirow{2}{*}{ Soil parameters } & \multicolumn{3}{|c|}{ Experimental variants } \\
\cline { 2 - 4 } & \multicolumn{1}{|c|}{ SH I } & \multicolumn{1}{c|}{ SH II } & \multicolumn{1}{c|}{ SH III } \\
\hline $\mathrm{pH}$ & $6.50 \pm 0.04 \mathrm{a}$ & $6.48 \pm 0.06 \mathrm{a}$ & $6.58 \pm 0.09 \mathrm{a}$ \\
\hline $\mathrm{EC}\left(\mu \mathrm{S} \mathrm{cm}^{-3}\right)$ & $87.57 \pm 3.25 \mathrm{a}$ & $87.72 \pm 1.67 \mathrm{a}$ & $89.44 \pm 2.29 \mathrm{a}$ \\
\hline $\mathrm{OM}(\%)$ & $6.20 \pm 0.16 \mathrm{a}$ & $6.22 \pm 0.23 \mathrm{a}$ & $6.52 \pm 0.27 \mathrm{a}$ \\
\hline $\mathrm{N}(\%)$ & $0.18 \pm 0.01 \mathrm{a}$ & $0.17 \pm 0.01 \mathrm{a}$ & $0.18 \pm 0.01 \mathrm{a}$ \\
\hline $\mathrm{P}\left(\mathrm{g} \mathrm{kg}^{-1}\right)$ & $1.02 \pm 0.01 \mathrm{a}$ & $0.99 \pm 0.00 \mathrm{a}$ & $0.99 \pm 0.00 \mathrm{a}$ \\
\hline $\mathrm{K}\left(\mathrm{g} \mathrm{kg}^{-1}\right)$ & $0.98 \pm 0.00 \mathrm{a}$ & $0.97 \pm 0.00 \mathrm{a}$ & $1.02 \pm 0.01 \mathrm{a}$ \\
\hline $\mathrm{Mg}\left(\mathrm{g} \mathrm{kg}^{-1}\right)$ & $2.22 \pm 0.01 \mathrm{~b}$ & $2.33 \pm 0.01 \mathrm{~b}$ & $2.94 \pm 0.01 \mathrm{a}$ \\
\hline $\mathrm{Ca}\left(\mathrm{g} \mathrm{kg}^{-1}\right)$ & $4.50 \pm 0.02 \mathrm{~b}$ & $4.83 \pm 0.01 \mathrm{~b}$ & $5.60 \pm 0.03 \mathrm{a}$ \\
\hline $\mathrm{Fe}\left(\mathrm{g} \mathrm{kg}^{-1}\right)$ & $11.85 \pm 0.01 \mathrm{a}$ & $11.96 \pm 0.02 \mathrm{a}$ & $12.10 \pm 0.04 \mathrm{a}$ \\
\hline $\mathrm{Pb}\left(\mathrm{mg} \mathrm{kg}^{-1}\right)$ & $635.6 \pm 3.7 \mathrm{a}$ & $637.7 \pm 5.4 \mathrm{a}$ & $639.1 \pm 8.1 \mathrm{a}$ \\
\hline${\mathrm{Cd}\left(\mathrm{mg} \mathrm{kg}^{-1}\right)}_{\mathrm{Zn}\left(\mathrm{g} \mathrm{kg}^{-1}\right)}^{25.70 \pm 0.48 \mathrm{a}}$ & $26.01 \pm 0.28 \mathrm{a}$ & $26.04 \pm 0.38 \mathrm{a}$ \\
\hline $\mathrm{Pb}_{\mathrm{bio}}\left(\mathrm{mg} \mathrm{kg}^{-1}\right)$ & $2.36 \pm 0.01 \mathrm{a}$ & $2.42 \pm 0.01 \mathrm{a}$ & $2.46 \pm 0.01 \mathrm{a}$ \\
\hline $\mathrm{Cd}_{\mathrm{bio}}\left(\mathrm{mg} \mathrm{kg}^{-1}\right)$ & $\mathrm{LOQ}$ & $\mathrm{LOQ}$ & \\
\hline $\mathrm{Zn}_{\mathrm{bio}}\left(\mathrm{mg} \mathrm{kg}^{-1}\right)$ & $110.10 \pm 6.67 \mathrm{a}$ & $107.42 \pm 4.11 \mathrm{a}$ & $95.66 \pm 13.19 \mathrm{a}$ \\
\hline
\end{tabular}

SH I - control plots, SH II - NPK fertilized plots, SH III - microbial inoculated plots, $\mathrm{EC}$ - electrical conductivity, OM - organic matter, bio - bioavailable fraction of heavy metals, LOQ - limit of quantification.

A lower-case letters $(a, b)$ denotes significant differences among soils samples taken from different plots at $\mathrm{P} \leq 0.05$ according to Fisher LSD test.

Values are means $\pm \mathrm{SE}(\mathrm{n}=3)$

\subsection{Gas exchange, plant pigment content and chlorophyll $a$ fluorescence measurements}

Gas exchange measurements were performed monthly (June - August) on each plot using Infra-Red Gas Analyser (Lc ProSD, ADC Bioscientific, UK) with measuring chamber set on climate condition $\left(21^{\circ} \mathrm{C}, 1500 \mathrm{PAR}, \mathrm{CO}_{2}\right.$ ambient $)$ For 
measurements from each plot 3 plant were selected and on each plant measurements were performed on two young fully developed leaves.

Plant pigment content measurements were performed monthly (June - August) on each plot using plant pigment content meter (Dualex Scientific+, FORCE-A, France). Measurements were performed on the same plants where gas exchange measurements were performed.

Chlorophyll $a$ fluorescence measurements were performed monthly (June August) on each plot using fluorimeter (Handy Plant Efficiency Analyzer, Hansatech Instruments Ltd, UK). Measurements were performed at night when samples were adapted to darkness, on the same plants where gas exchange and plant pigment content measurements were performed.

\subsection{Concentration of heavy metals and primary mineral macronutrients in plants}

Three plant shoots from each of investigated plants were collected at the end of third growing season (October 2016) on each plot. Concentration of metals in the plant shoots was determined by hot plate digestion and flame atomic absorption spectrometry (SpektrAA 300, Varian INC., USA). Plant samples were digested in nitric and perchloric acid (4:1 v/v) [16]. Total nitrogen concentration $(\mathrm{N})$ in plant shoots was assessed using the method described by Bremner [17], whereas total phosphorus $(\mathrm{P})$ and potassium $(\mathrm{K})$ concentration in plant shoots were assessed using ICP (Liberty 220, Varian, USA) in previously digested samples.

\subsection{Statistical analysis}

One-way ANOVA followed by post-hoc LSD test at $\mathrm{P} \leq 0.05$ were used to distinguish differences between experimental variants during each month as well as to distinguish differences between values obtained during June, July and August measurements separately for each experimental variant.

\section{RESULTS AND DISSCUSSION}

\subsection{Soil characteristics}

Physical and chemical soil parameters are presented in Tab. 1 according to Pogrzeba et al. [12]. Heavy metal concentrations in the soil exceeded Polish limits for food crop production [18]. The $\mathrm{pH}$ was almost neutral, followed by high content of organic matter (OM) and low electrical conductivity (EC). Despite low $\mathrm{Pb}$ bioavailability, presented results indicate high concentration of $\mathrm{Cd}$ and $\mathrm{Zn}$ bioavailable forms. There is almost no differences between plots in initial soil characteristic what indicate that soil is highly homogenous. 


\subsection{Gas exchange parameters}

Gas exchange parameters are presented in Fig. 1. Photosynthesis rate (Fig. 1a) showed no differences between experimental variants within each month, while considering differences between month, it was found that photosynthesis rate decrease consequently from June to August. Despite the fact that there were no differences between experimental variants, there is tendency suggesting that NPK treated plants showed the best photosynthesis rate in the June while the worst in the August.

The highest transpiration rate (Fig. 1b) were found in June for plant treated with chemical fertilizer, lower for inoculum treated plants and the lowest for control. It was found that there were no differences between experimental variants in August, however obtained values were about $43 \%$ lower when compare to June measurements. Values obtained during August measurements indicate the same tendency between experimental variants as found in photosynthesis rate. Transpiration rate measured in June was the highest among all experimental variants. Values obtained in August were about 30\% higher when compare to those obtained in July.

There is dearth of papers considering direct measurement of photosynthesis using IRGA on Sida hermaphrodita. Kocon and Jurga [13] performed this type of measurements on $S$. hermaphrodita, however those were performed once a year, in spring, on young plants, with use of different chamber set up than used in the present study. Rosenthal et al. [19] performed continuous measurements of photosynthesis on Glycine max during two growing seasons (from June September). They reported start of photosynthesis rate parameter decrease at the turn of August and September. Constant decrease of photosynthesis rate during growing season in present report could be associated with presence of HMs in soil and induced senescence by reactive oxygen species (ROS) [20], this fact could be additionally supported by month by month decreasing tendency visible for values obtained for chlorophyll content and chlorophyll fluorescence vitality index $\left(\mathrm{F}_{\mathrm{v}} / \mathrm{F}_{\mathrm{m}}\right)$.

\subsection{Plant pigment content}

Chlorophyll content measured in June showed the highest value for plants treated with chemical fertilizer and untreated, significantly lower values were found for inoculated plants. In July, it was found increasing tendency of chlorophyll content for control and inoculum treated plants while decrease was reported for NPK treated. The chlorophyll content in July was higher by about 3 relative units (r.u.) in control and inoculum treated plants when compare to NPK fertilized. In August decrease of chlorophyll content in all experimental variants was found. There were no statistically significant differences between experimental variants, however tendency with the lowest value for NPK treated plants still occur in August. 

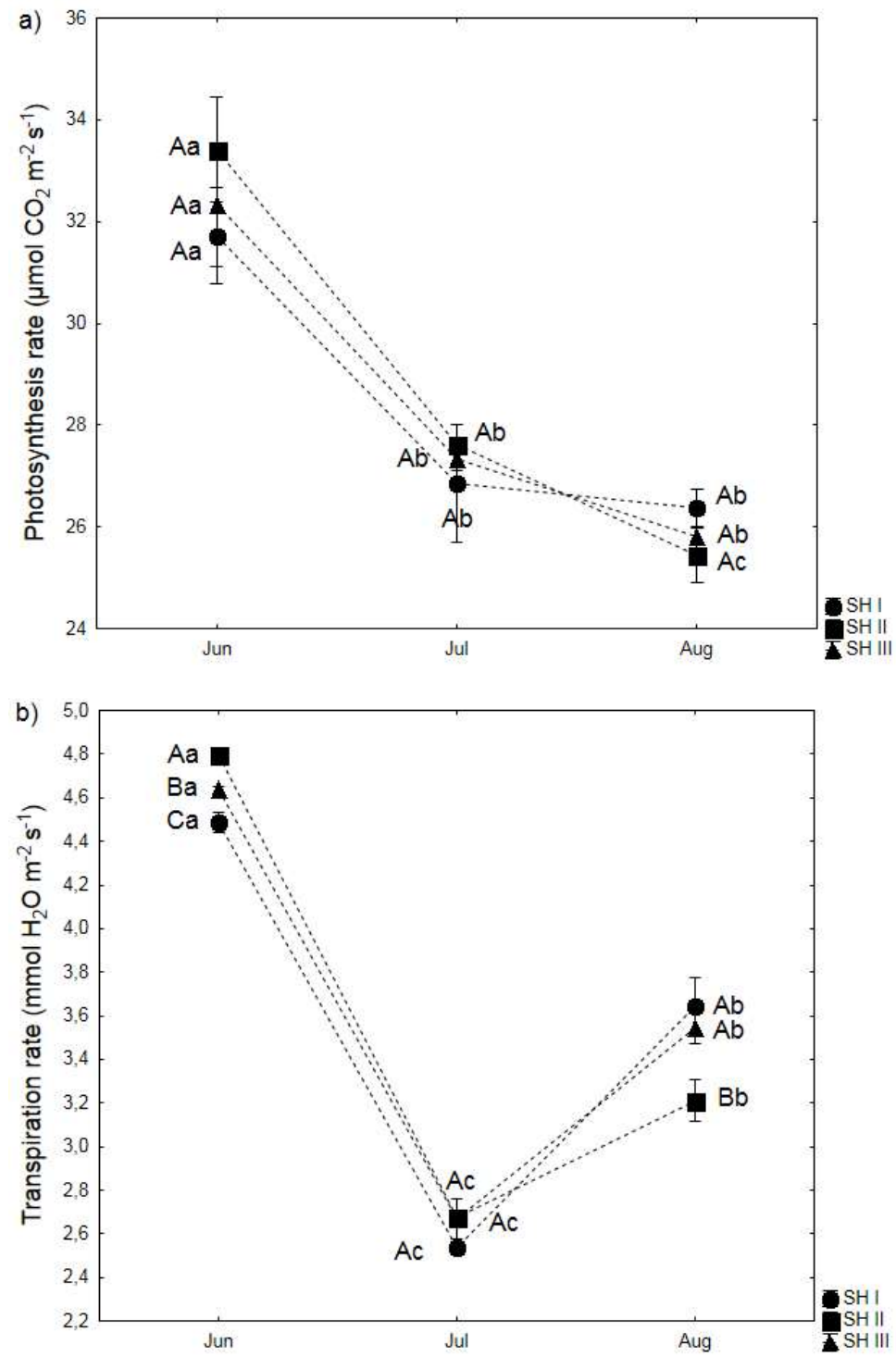

Fig. 1. Influence of NPK fertilization (SH II) and microbial inoculation (SH III) on (a) photosynthesis rate and (b) transpiration rate of Sida hermaphrodita in June, uly and August 2016 growing season. Values are means \pm SE $(n=18)$. Capital letters $(\mathrm{A}, \mathrm{B}, \mathrm{C})$ denote significant differences among parameters in plants on different plots within one month, while lower case letters $(a, b, c)$ denote significant differences among parameters between months within one experimental variant at $\mathrm{P} \leq 0.05$ according to

Fisher LSD test. 
Anthocyanins content was on the same level in each experimental variant on June and July. High decrease of anthocyanins was found in August for each experimental variant when compare to June and July. Although, there were no statistically significant differences between experimental variants the highest anthocyanins content was found for plant treated with NPK fertilizer while the lowest for plants treated with microbial inoculum.

The progression of leaf senescence is most commonly monitored as chlorophyll degradation [21,22]. Anthocyanin accumulation begins shortly after the onset of chlorophyll decline, typically before any visible change in leaf color appear. This could demonstrate a direct association between anthocyanin production and the period of increased vulnerability to photoinhibition during senescence, and suggest that anthocyanins may perform a photoprotective role in autumnal foliage. In addition, under stressful conditions, even moderate irradiances can induce photoinhibitory damage to plants [23]. This statement could additionally be supported by the fact that there were significant negative Pearson's correlations between anthocyanins and chlorophyll $(\mathrm{r}=-0.621, \mathrm{p}=0.000)$, photosynthesis rate $(\mathrm{r}=-0.399, \mathrm{p}=0.000)$ and $\mathrm{F}_{\mathrm{v}} / \mathrm{F}_{\mathrm{m}}(\mathrm{r}=-0.435, \mathrm{p}=0.000)$

\subsection{Chlorophyll $a$ fluorescence parameters}

The most common parameters obtained from chlorophyll $a$ fluorescence measurements are $F_{v} / F_{m}$ (Maximum quantum yield of primary photochemical reactions) that indicates the probability of trapping the energy of absorbed photons by PSII reaction centres and $\mathrm{PI}_{\mathrm{ABS}}$ (Performance index) an indicator of PSII functional activity normalized to the absorbed energy [24,25].

Those parameters are usually described as vitality indices [25]. The $\mathrm{F}_{\mathrm{v}} / \mathrm{F}_{\mathrm{m}}$ parameter was the highest for fertilized plants while the lowest for control plants in June. There were no differences between experimental variants in July, however in August NPK fertilized plants showed the lowest $F_{v} / F_{m}$ values when compare to the other experimental variants. General tendency indicate that $\mathrm{F}_{\mathrm{v}} / \mathrm{F}_{\mathrm{m}}$ parameter consequently decrease from June to August. Performance index showed slightly different behavior when compare to $\mathrm{F}_{\mathrm{v}} / \mathrm{F}_{\mathrm{m}}$. The $\mathrm{PI}_{\mathrm{ABS}}$ in June was $23 \%$ lower in control plants and those treated with microbial inoculum when compare to NPK fertilized plants. There were no differences between experimental variants in July while considering $\mathrm{PI}_{\mathrm{ABS}}$ parameter. The control plants showed significantly lower values of $\mathrm{PI}_{\mathrm{ABS}}$ when compare to inoculum treated plant in August. There were no differences between NPK treated plants and other experimental variants. Control plants did not differ significantly between months. Inoculum treated plants had the same value of $\mathrm{PI}_{\mathrm{ABS}}$ in June and July while decrease of this parameter was reported in August. The $\mathrm{PI}_{\mathrm{ABS}}$ measured for NPK treated plants decreased in July when compare to June, however it increased in August when compare to July to value similar to this obtained in June. 

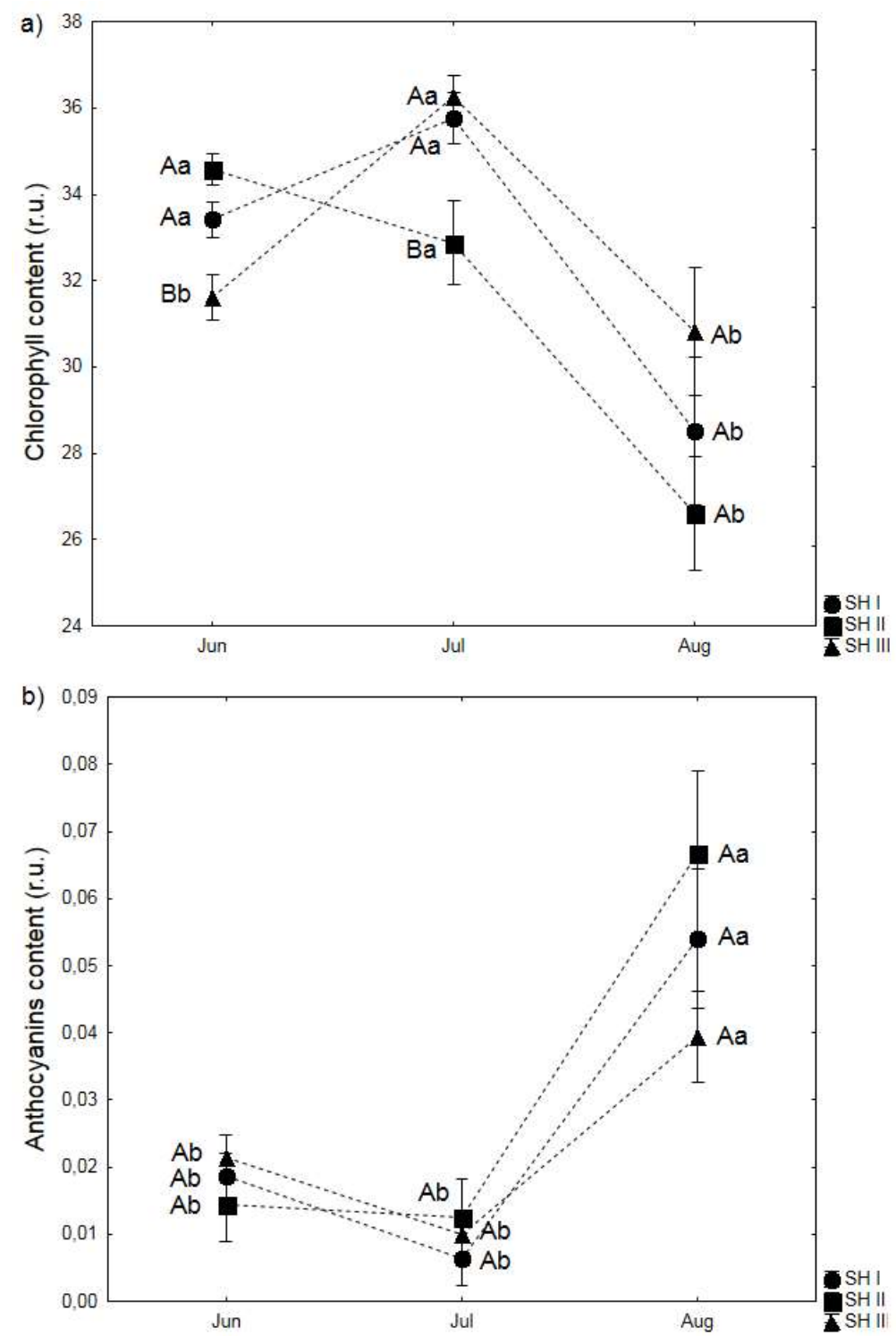

Fig. 2. Influence of NPK fertilization (SH II) and microbial inoculation (SH III) on (a) chlorophyll content and (b) anthocyanins content of Sida hermaphrodita in June, July and August 2016 growing season. Values are means $\pm \operatorname{SE}(n=12)$. Capital letters (A, B, C) denote significant differences among parameters in plants on different plots within one month, while lower case letters $(a, b, c)$ denote significant differences among parameters between months within one experimental variant at $\mathrm{P} \leq 0.05$ according to Fisher LSD test. 

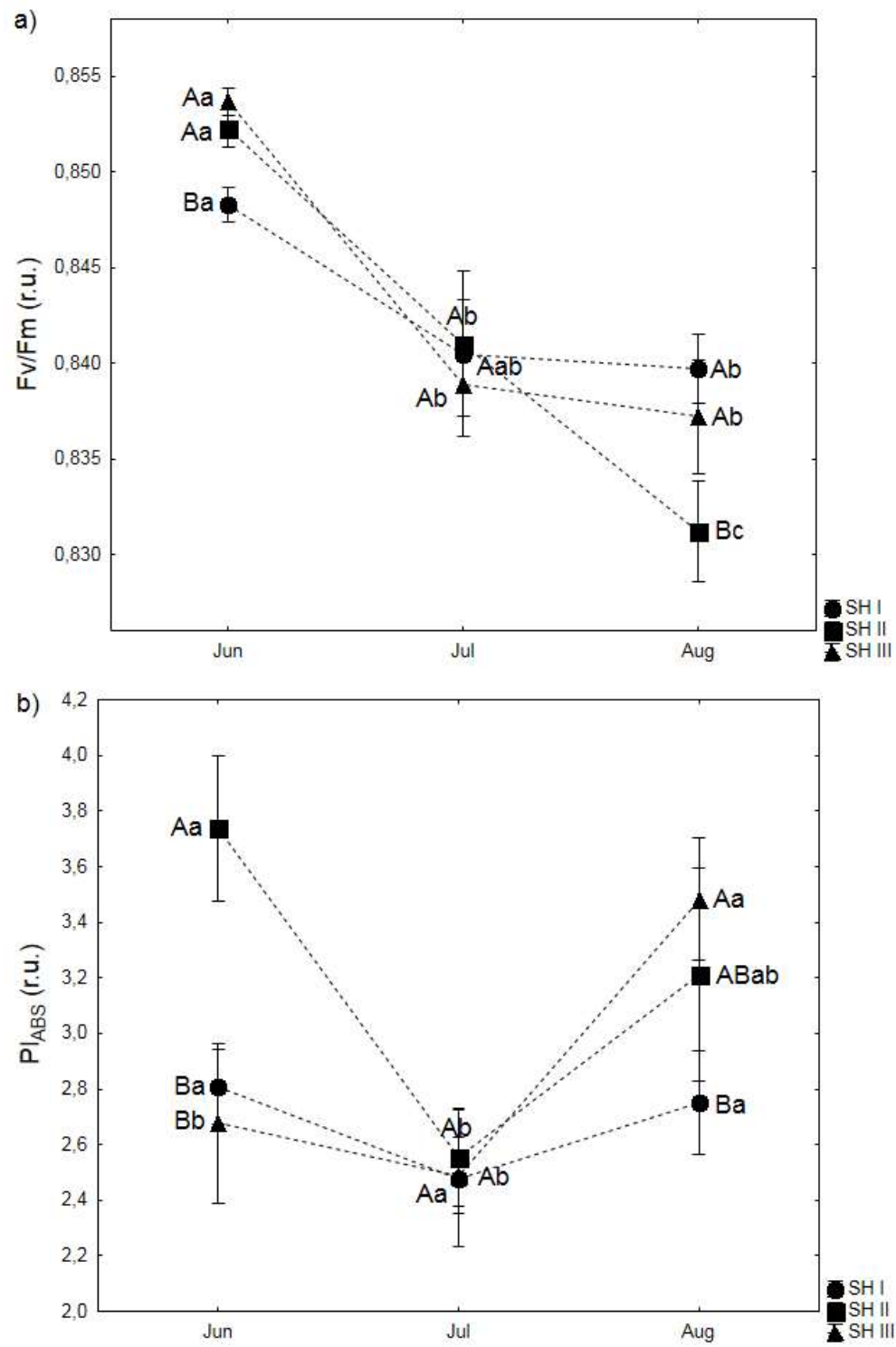

Fig. 3. Influence of NPK fertilization (SH II) and microbial inoculation (SH III) on (a) $\mathrm{F}_{\mathrm{v}} / \mathrm{F}_{\mathrm{m}}$ and (b) $\mathrm{PI}_{\mathrm{ABS}}$ of Sida hermaphrodita in June, July and August 2016 growing season. Values are means $\pm \mathrm{SE}(\mathrm{n}=12)$. Capital letters $(\mathrm{A}, \mathrm{B}, \mathrm{C})$ denote significant differences among parameters in plants on different plots within one month, while lower case letters $(a, b, c)$ denote significant differences among parameters between months within one experimental variant at $\mathrm{P} \leq 0.05$ according to Fisher LSD test. 


\subsection{Heavy metals and mineral macronutrients concentration in plant shoots}

Heavy metals and mineral macronutrients concentration in plants shoots was presented on Table 2. It was found that on each plot $\mathrm{Pb}$ concentration was below detection limit, this phenomenon could be associated with low bioavailability of this element in the soil [26]. Cadmium concentration in shoots was the highest in NPK fertilized plants, while it was about $24 \%$ lower in control and inoculum treated plants. Similar tendency was found for $\mathrm{Zn}$ shoot concentration, however control and NPK fertilized plants showed significantly higher values by about $30 \%$ and $41 \%$, respectively when compare to inoculum treated plants. Control plants showed the highest shoot $\mathrm{N}$ concentration among experimental variants. It was $0.23 \%$ and $0.30 \%$ higher when compare to NPK and inoculum treated plants respectively. Similar tendency was observed for shoot P concentration. The highest shoot K concentration was found simultaneously for NPK and inoculum treated plants and it was nearly $20 \%$ higher when compare to control plants.

The highest heavy metals concentration in NPK treated plant shoots (particularly $\mathrm{Cd}$ and $\mathrm{Zn}$ ) could be associated with application of chemical fertilizer which could increase the mobility of heavy metals by reducing $\mathrm{pH}$ value. This phenomenon occurs due to the presence of $\mathrm{NH}_{4}{ }^{+}$in chemical fertilizers as the N-source, which results in $\mathrm{H}^{+}$extrusion by the roots and acidification of the soil [27]. Similar phenomenon was observed for Miscanthus x giganteus on the same field [28]. Although, concentration of $\mathrm{Cd}$ and $\mathrm{Zn}$ in plants shoots did not exceed toxic concentration describe by Kabata-Pedias [29] it could slightly affect photosynthetic apparatus efficiency, especially in senescent plants due to its higher sensitivity to stress factors. This could explain results obtained for NPK fertilized plants comparing to other treatments. The highest value of chlorophyll content, $\mathrm{F}_{\mathrm{v}} / \mathrm{F}_{\mathrm{m}}$, photosynthesis rate and transpiration rate in June for NPK fertilized plants could be associated with better supplementation, however the lowest value of those parameters for the same plants in August could be associated with combined effect of senescence and the highest HM concentration in NPK fertilized plants shoots. The lowest concentration of $\mathrm{N}$ and $\mathrm{P}$ in inoculated plant shoots could be associated with competition between plant roots and applied monthly microorganisms as well as indigenous rhizosphere microorganisms. This phenomenon could be associated with molasses included in inoculum formula, which derived easily decomposable $\mathrm{C}$ and prime microorganisms (microbial activation) for achieving additional $\mathrm{N}$ from soil organic matter decomposition [30]. 
PHOTOSYNTHETIC APPARATUS EFFICIENCY OF SIDA HERMAPHRODITA

CULTIVATED ON HEAVY METALS CONTAMINATED ARABLE LAND UNDER

VARIOUS FERTILIZATION REGIMES

Table 2. Heavy metals and primary macronutrients concentration in plant shoots

\begin{tabular}{|r|r|r|r|}
\hline & \multicolumn{1}{|c|}{ SH I } & \multicolumn{1}{c|}{ SH II } & \multicolumn{1}{c|}{ SH III } \\
\hline $\mathrm{Pb}\left(\mathrm{mg} \mathrm{kg}^{-1}\right)$ & LOQ & LOQ & LOQ \\
\hline $\mathrm{Cd}\left(\mathrm{mg} \mathrm{kg}^{-1}\right)$ & $2.46 \pm 0.47 \mathrm{~b}$ & $3.06 \pm 0.10 \mathrm{a}$ & $2.23 \pm 0.39 \mathrm{~b}$ \\
\hline $\mathrm{Zn}\left(\mathrm{mg} \mathrm{kg}^{-1}\right)$ & $163.3 \pm 8.6 \mathrm{~b}$ & $195.7 \pm 12.8 \mathrm{a}$ & $117.2 \pm 10.1 \mathrm{c}$ \\
\hline $\mathrm{N}(\%)$ & $0.74 \pm 0.03 \mathrm{a}$ & $0.51 \pm 0.03 \mathrm{~b}$ & $0.44 \pm 0.03 \mathrm{c}$ \\
\hline $\mathrm{P}\left(\mathrm{mg} \mathrm{kg}^{-1}\right)$ & $866.2 \pm 66.9 \mathrm{a}$ & $659.6 \pm 72.6 \mathrm{~b}$ & $511.2 \pm 42.6 \mathrm{c}$ \\
\hline $\mathrm{K}\left(\mathrm{g} \mathrm{kg}^{-1}\right)$ & $9.28 \pm 0.87 \mathrm{~b}$ & $11.11 \pm 0.56 \mathrm{a}$ & $11.66 \pm 1.11 \mathrm{a}$ \\
\hline
\end{tabular}

SH I - control plots, SH II - NPK fertilized plots, SH III - microbial inoculated plots, LOQ - limit of quantification. A lower-case letters $(a, b, c)$ denotes significant differences among elements concentration in plant shoots taken from different plots at $\mathrm{P} \leq 0.05$ according to Fisher LSD test.

Values are means \pm SE $(n=9)$

\section{CONCLUSIONS}

In conclusion, application of different fertilizers did not affect photosynthesis apparatus efficiency when compared to control. Heavy metals concentration in shoots did not exceed toxic concentration thresholds for higher plants. Based on chlorophyll and anthocyanins content it could be assumed that plant senescence begins at turn of July and August. Senescence could increase vulnerability of photosynthetic apparatus to heavy metal toxicity. It could be summarized that Sida hermaphrodita is plant suitable for cultivation on land contaminated with HMs under different fertilization regimes.

\section{ADDITIONAL INFORMATION}

The project is implemented under Maria Curie Skłodowska Actions of the 7 Framework Programme of the EU (Grant agreement No. 610797). Research received additionally financial support from Institute for Ecology of Industrial Area statutory founds.

\section{REFERENCES}

1. McKendry P.: Energy production from biomass (part 1): overview of biomass, Bioresource technology, 83 (2002) 37-46.

2. Hu H., Wang L., Wang Q., Jiao L., Hua W., Zhou Q., Huang X.: Photosynthesis, chlorophyll fluorescence characteristics, and chlorophyll 
content of soybean seedlings under combined stress of bisphenol A and cadmium, Environmental toxicology and chemistry, 33 (2014) 2455-2462.

3. Massacci A., Nabiev S.M., Pietrosanti L., Nematov S.K., Chernikova T.N., Thor K., Leipner J.: Response of the photosynthetic apparatus of cotton (Gossypium hirsutum) to the onset of drought stress under field conditions studied by gas-exchange analysis and chlorophyll fluorescence imaging, Plant Physiology and Biochemistry, 46 (2008) 189-195.

4. Borawska-Jarmułowicz B., Mastalerczuk G., Pietkiewicz S., Kalaji, M.H.: Low temperature and hardening effects on photosynthetic apparatus efficiency and survival of forage grass varieties, Plant Soil and Environment 60 (2014) 177-183.

5. Liang Y., Urano D., Liao K.L., Hedrick T.L., Gao Y., Jones A.M.: A nondestructive method to estimate the chlorophyll content of Arabidopsis seedlings, Plant methods, 13 (2017) 26.

6. Directive 2009/28/EC of the European Parliament and of the Council of 23 April 2009 on the promotion of the use of energy from renewable sources and amending and subsequently repealing Directives 2001/77/EC and 2003/30/EC

7. Scarlat N., Banja M.: Possible impact of 2020 bioenergy targets on European Union land use. A scenario-based assessment from national renewable energy action plans proposals, Renewable and Sustainable Energy Reviews, 18 (2013) 595-606.

8. Oleszek W., Terelak H., Maliszewska-Kordybach B., Kukula S.: Soil, Food and Agroproduct Contamination Monitoring in Poland, Polish Journal of Environmental Studies, 12 (2003) 261-268.

9. Burzyński M., Kłobus G.: Changes of photosynthetic parameters in cucumber leaves under $\mathrm{Cu}, \mathrm{Cd}$, and $\mathrm{Pb}$ stress. Photosynthetica, 42 (2004) 505-510.

10. Van Ginneken L., Meers E., Guisson R., Ruttens A., Elst K., Tack F.M., Dejonghe W., et al.: Phytoremediation for heavy metal-contaminated soils combined with bioenergy production, Journal of Environmental Engineering and Landscape Management, 15 (2007) 227-236.

11. Sanderson M.A., Adler P.R.: Perennial forages as second generation bioenergy crops, International Journal of Molecular Sciences, 9 (2008) 768-788.

12. Pogrzeba M., Krzyżak J., Rusinowski S. Werle S., Hebner A., Milandru A.: Case study on phytoremediation driven energy crop production using Sida hermaphrodita, International Journal of Phytoremediation (in press)

13. Kocoń A., Jurga B.: The evaluation of growth and phytoextraction potential of Miscanthus x giganteus and Sida hermaphrodita on soil contaminated simultaneously with $\mathrm{Cd}, \mathrm{Cu}, \mathrm{Ni}, \mathrm{Pb}$, and $\mathrm{Zn}$, Environmental Science and Pollution Research, 24 (2017) 4990-5000. 
14. Dz.U. 2016 poz. 1395. Decision of the Polish Ministry of Environment on the assessment of soil contamination.

15. El Bassam N.: Energy crops guide, in: Handbook of bioenergy crops, ed. El Bassam N., UK, Earthscan 2010, 93 - 399.

16. Schierup H.H., Larsen V.J, Macrophyte cycling of zinc, copper, lead and cadmium in the littoral zone of a polluted and a non-polluted lake. I. Availability, uptake and translocation of heavy metals in Phragmites australis (Cav.), Trin, Aquatic Botany, 11 (1981) 197-210.

17. Bremner J.M.: Nitrogen - total, In: Methods of Soil Analysis, Part 3: Chemical Method, eds. Sparks D.L., Page A.L., Helmke P.A., Loeppert R.H., Soltanpour P.N., Tabatabai M.A., Johnston C.T., Sumner M.E., Madison, Wisconsin, USA, American Society of Agronomy and Soil Science Society of America 1996 1085-1121.

18. Dz.U. 2016 poz. 1395. Decision of the Polish Ministry of Environment on the assessment of soil contamination.

19. Rosenthal D.M., Ruiz-Vera U.M., Siebers M.H., Gray S.B., Bernacchi C.J., Ort D.R.: Biochemical acclimation, stomatal limitation and precipitation patterns underlie decreases in photosynthetic stimulation of soybean (Glycine $\max )$ at elevated $\left[\mathrm{CO}_{2}\right]$ and temperatures under fully open air field conditions, Plant Science, 226 (2014) 136-146.

20. Jajic I., Sarna T., Strzalka K.: Senescence, stress, and reactive oxygen species, Plants, 4 (2015) 393-411.

21. Grover A., Mohanty P.: Leaf senescence-induced alterations in structure and function of higher plant chloroplasts, In: Photosynthesis: Photoreactions to Plant Productivity, dds. Abrol Y.P., Mohanty P., Govindjee, Dordrecht, Kluwer Academic Publishers 1993, 225-255.

22. Mos M., Banks S.W., Nowakowski D.J., Robson P.R.H., Bridgwater A.V., Donnison I.S.: Impact of Miscanthus $x$ giganteus senescence times on fast pyrolysis bio-oil quality, Bioresource technology, 129 (2013) 335-342.

23. Hoch,W.A., Zeldin E.L., McCown B.H.: Physiological significance of anthocyanins during autumnal leaf senescence, Tree Physiology, 21(2001) 18

24. Kalaji H.M., Oukarroum A., Alexandrov V., Kouzmanova M., Brestic M., Zivcak M., Goltsev V., et al.: Identification of nutrient deficiency in maize and tomato plants by in vivo chlorophyll a fluorescence measurements, Plant physiology and biochemistry, 81 (2014) 16-25.

25. Goltsev V.N., Kalaji H.M., Paunov M., Bąba W., Horaczek T., Mojski J., Allakhverdiev S.I., et al.: Variable chlorophyll fluorescence and its use for assessing physiological condition of plant photosynthetic apparatus, Russian journal of plant physiology, 63 (2016) 869-893. 
26. Sitko K., Rusinowski S., Kalaji H.M., Szopiński M., Malkowski E.:. Photosynthetic Efficiency as Bioindicator of Environmental Pressure in A. halleri. Plant Physiology, (2017) pp.00212.2017 (available on-line: https://doi.org/10.1104/pp.17.00212)

27. Magdoff F., Lanyon L., Liebhardt B., Nutrient cycling, transformations, and flows: implications for a more sustainable agriculture. Adv. Agron. 60 (1997) 1-73.

28. Pogrzeba M., Rusinowski S., Sitko K., Krzyżak J., Skalska A., Małkowski E., Kalaji H. M., et al.: Relationships between soil parameters and physiological status of Miscanthus x giganteus cultivated on soil contaminated with trace elements under NPK fertilisation vs. microbial inoculation, Environmental Pollution, 225 (2017) 163-174.

29. Kabata-Pedias A.: Trace Elements in Soil and Plants, fourth ed., USA, CRC press 2011.

30. Kuzyakov Y.: Factors affecting rhizosphere priming effects, Journal of Plant Nutrition and Soil Science, 165 (2002) 382-396.

\section{WYDAJNOŚC APARATU FOTOSYNTETYCZNEGO SIDA HERMAPHRODITA UPRAWIANEGO NA GLEBIE ZANIECZYSZCZONEJ METALAMI CIĘŻKIMI W WARUNKACH ZRÓŻNICOWANEGO NAWOŻENIA}

\section{Streszczenie}

Tereny zanieczyszczone i odłogowane stanowią opcję dla uprawy roślin na cele energetyczne, szczególnie jeśli weźmie się pod uwagę rozporządzenia dyrektywy Unii Europejskiej w sprawie promowania stosowania energii ze źródeł odnawialnych (2009/28/EC). Spełnienie jej wymogów może być po części zrealizowane poprzez uprawę roślin energetycznych drugiej generacji. Zastosowanie takiego podejścia pozwoli nie tylko pokryć lokalne zapotrzebowanie na odnawialne źródła energii, ale także wspomóc zarządzanie terenami nieprzydatnymi $\mathrm{w}$ produkcji roślin na cele żywnościowe oraz paszowe. W przedstawionej pracy badano wpływ zastosowania zróżnicowanego nawożenia na parametry fizjologiczne ślazowca pensylwańskiego uprawianego na glebie zanieczyszczonej metalami ciężkimi. Rośliny nawożone standardowymi nawozami mineralnymi charakteryzowały się wyższymi wartościami parametrów fizjologicznych na początku sezonu wegetacyjnego, podczas gdy na końcu sezonu wegetacyjnego wyższe wartości stwierdzono dla roślin w wariancie kontrolnym i szczepionką mikrobiologiczną. Nawożenie mineralne spowodowało wyższe zawartości Cd i Zn w roślinach, podczas gdy rośliny traktowane szczepionką mikrobiologiczną miały wyższe zawartości $\mathrm{K}$ oraz najniższe zawartości N i P w częściach nadziemnych. Stwierdzone zawartości Pb, Cd I Zn w częściach nadziemnych ślazowca pensylwańskiego nie powinny mieć negatywnego wpływu na stan aparatu fotosyntetycznego i wydajność produkcji biomasy. W związku 
PHOTOSYNTHETIC APPARATUS EFFICIENCY OF SIDA HERMAPHRODITA CULTIVATED ON HEAVY METALS CONTAMINATED ARABLE LAND UNDER VARIOUS FERTILIZATION REGIMES

$\mathrm{z}$ tym roślina ta może być przydatna w produkcji biomasy na cele energetyczne na ternach zanieczyszczonych.

Słowa kluczowe: Natężenie fotosyntezy, fluorescencja chlorofilu, $\mathrm{Cd}, \mathrm{Pb}, \mathrm{Zn}$, starzenie

Editor received the manuscript: 31.08 .2017 